\title{
Data report: foraminiferal stable isotope and percent calcium carbonate analysis from IODP Expedition 318 Hole U1361A ${ }^{1}$
}

\author{
Matthew DeCesare ${ }^{2}$ and Stephen Pekar ${ }^{3}$
}

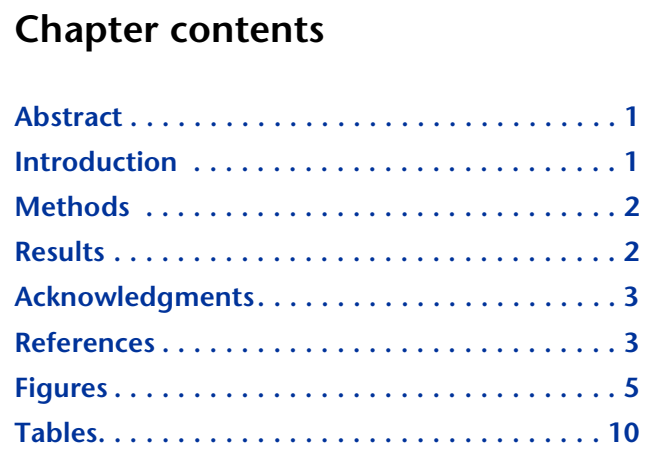

${ }^{1}$ DeCesare, M., and Pekar, S., 2016. Data report: foraminiferal stable isotope and percent calcium carbonate analysis from IODP Expedition 318 Hole U1361A. In Escutia, C., Brinkhuis, H., Klaus, A., and the Expedition 318 Scientists, Proceedings of the Integrated Ocean Drilling Program, 318: Tokyo (Integrated Ocean Drilling Program Management International, Inc.).

doi:10.2204/iodp.proc.318.202.2016

${ }^{2}$ Department of Geology \& Geophysics, Louisiana State University, E235 Howe Russell, Baton Rouge LA 70803, USA. mdeces3@Isu.edu

${ }^{3}$ Department of Earth and Environmental Sciences, City University of New York, Queens College, 6530 Kissena Blvd, Flushing NY 11367, USA.

\begin{abstract}
A newly recognized carbonate preservation event (CPE) dated between 11 and $12 \mathrm{Ma}$ was identified in Hole U1361A during Integrated Ocean Drilling Program Expedition 318 in the Southern Ocean based on $\mathrm{CaCO}_{3}$ content and the preservation of foraminiferal tests. High carbonate content occurs within the interval between 311.60 and 349.99 meters below seafloor, whereas $\mathrm{CaCO}_{3}$ content was typically near $1 \mathrm{wt} \%$ for the rest of the core. In addition, benthic and planktonic foraminifers were relatively abundant. However, stable isotope measurements carried out within this interval contained unrealistic values, which we ascribe to postdepositional diagenetic alteration by the release of methane. This prohibited quantification of temperature, ice volume, and salinity.

The CPE identified at Hole U1361A was also observed at Ocean Drilling Program Site 689, which is correlated to the Mi5 glaciation. We hypothesize that this Southern Ocean CPE and the diagenetic alteration of foraminifers were due to both the Mi5 glaciation and reorganization of ocean circulation.
\end{abstract}

\section{Introduction}

Integrated Ocean Drilling Program (IODP) Expedition 318 Hole $\mathrm{U} 1361 \mathrm{~A}\left(64.2457^{\circ} \mathrm{S}, 143.5320^{\circ} \mathrm{E}\right)$ is located on the George V Land continental rise (3466 meters below sea level]) $\sim 280 \mathrm{~km}$ from the coast (Fig. F1). The purpose of drilling this site was to refine the history of climatic and oceanic changes from the middle Miocene to the Pleistocene and to determine the relative stability of the East Antarctic Ice Sheet (EAIS), especially during warm intervals (e.g., Pliocene) (see the "Site U1361" chapter [Expedition 318 Scientists, 2011b]).

The state of the EAIS after the middle Miocene is a topic of controversy that created two schools of thought among paleoclimate researchers (Miller and Mabin, 1998). "Stabilists" cite evidence that a polar Antarctic ice sheet was established by $14 \mathrm{Ma}$. In contrast, a considerable amount of evidence suggests a polythermal ice sheet existed from $\sim 33$ to $2.5 \mathrm{Ma}$ (Wilson et al., 2002). Current research indicates that the thermal regime of the EAIS varied by location during the Miocene, with a polar EAIS grounded in the Dry Valleys (Marchant et al., 1996; Sugden, 1996) and a polythermal EAIS occupying Wilkes Land and Prydz Bay (Whitehead et al., 
2006). These differences in thermal regimes are likely due to the EAIS being grounded below sea level at George V Land and Prydz Bay, making them more susceptible to climactic warming (see the "Site U1361" chapter [Expedition 318 Scientists, 2011b]); Whitehead et al., 2006).

In this study, moderately high resolution stable isotopic ratio (from planktonic and benthic foraminifers) and $\mathrm{CaCO}_{3}$ content records were developed from samples taken from Cores 318-U1361A-34X through 37X (311.60-349.99 meters below seafloor [mbsf $]$ ). The purpose of these data were to evaluate cryospheric and Southern Ocean changes during the middle to late Miocene. The $\mathrm{CaCO}_{3}$ content helped identify a new carbonate preservation event (CPE) in the Southern Ocean (DeCesare, 2014). However, diagenesis affected the stable isotope records, limiting our interpretation of cryospheric and oceanographic changes during this study interval.

\section{Methods}

\section{Sample preparation and foraminifer identification}

Sediment samples from Hole U1361A were weighed and then dried in an oven at $50^{\circ} \mathrm{C}$ for $24 \mathrm{~h}$. The dried samples were soaked in a "Calgon solution" (5.5 g of Fisher Scientific laboratory grade sodium metaphosphate $\left(\mathrm{NaPO}_{3}\right)_{6}$ mixed with $\left.1 \mathrm{~L} \mathrm{H}_{2} \mathrm{O}\right)$ to help break down the sediment. The slurry was decanted into a $63 \mu \mathrm{m}$ sieve and gently washed with water to flush out silt- and clay-sized particles. The sediment was then separated into 425-355, 355-250, 250-125, and $125-63 \mu \mathrm{m}$ size fractions by dry sieving. Planktonic and benthic specimens $>63 \mu \mathrm{m}$ were picked under a reflected light binocular microscope with a fine paintbrush and separated by species. Visual inspection of the foraminiferal tests indicated excellent preservation, often with a glassy appearance. The following species were picked for isotopic analysis: Oridorsalis umbonatus, Gyroidinoides soldani, Epistominella exigua, Cibicidoides wuellerstorfi, Cibicidoides bradyi, and Globigerina bulloides. Specimens were placed in double distilled water and sonicated for 510 s using a Bransonic ultrasonic cleaner prior to stable isotope analysis.

\section{Stable isotopes}

The cleaned benthic and planktonic foraminifers were first sent to the stable isotope laboratory at Lamont-Doherty Earth Observatory (USA) for $\delta^{18} \mathrm{O}$ and $\delta^{13} \mathrm{C}$ analysis. A VG Optima isotope-ratio mass spec- trometer equipped with a multiprep carbonate preparation module with long-term precision of $\pm 0.07 \%$ o for $\delta^{18} \mathrm{O}$ and $\pm 0.05 \%$ o for $\delta^{13} \mathrm{C}$ was used to collect stable isotope data. Foraminifers were also analyzed at the Stable Isotope Laboratory at Rutgers University (USA) using a Micromass Optima mass spectrometer with an attached multiprep device with analytical error $(1 \sigma)$ of $\pm 0.08 \%$ for $\delta^{18} \mathrm{O}$ and $\pm 0.05 \%$ for $\delta^{13} \mathrm{C}$.

Foraminifers were reacted in $100 \%$ phosphoric acid at $90^{\circ} \mathrm{C}$ for $10 \mathrm{~min}$, and the evolved $\mathrm{CO}_{2}$ was collected in a liquid nitrogen cold finger. Ratios are reported in standard delta notation in parts per thousand (per mil; \%o) $d=\left[\left(R_{\text {sample }} / R_{\text {standard }}\right)-1\right] \times 1000$ where $R={ }^{18} \mathrm{O} /{ }^{16} \mathrm{O}$ or ${ }^{13} \mathrm{C} /{ }^{12} \mathrm{C}$, relative to Vienna-Pee Dee Belemnite $\left(\delta^{18} \mathrm{O}\right.$ and $\left.\delta^{13} \mathrm{C}_{\text {VPDB }}\right)$ through the analysis of an in-house laboratory standard (RGF1). This standard is routinely calibrated to National Bureau of Standards NBS-19 to ensure consistency in reported values.

\section{Age model}

The age model for Hole U1361A was constructed using the geomagnetic Chron C5n.2n (o), at $11.04 \mathrm{Ma}$ and the biostratigraphic datum the first occurrence of Denticulopsis dimorpha s.l. at 12.4 Ma (Fig. F2). This resulted in an age range of 11.0-12.0 Ma for the study interval between 311.60 and 349.99 mbsf. In addition, the carbonate preservation event was correlated to a similar preservation event at Ocean Drilling Program Site 689 in the Weddell Sea (DeCesare, 2014), which has a robust magnetostratigraphic age model (Speiß, 1990). This enabled a more precise dating of the event to 11.9-10.5 Ma (DeCesare, 2014).

\section{Calcium carbonate weight percent and methane concentration}

For discussion of calcium carbonate weight percent and methane concentration, see the "Methods" chapter (Expedition 318 Scientists, 2011a).

\section{Results}

\section{Calcium carbonate content}

During Expedition 318, four Cores (34X-37X; $311.60-349.99 \mathrm{mbsf})$, averaging $100 \%$ recovery, were collected from Hole U1361A. These cores contained the only significant calcium carbonate $\left(\mathrm{CaCO}_{3}\right)$ preservation within the Miocene section (Fig. F3). Carbonate preservation was typically $<1 \%$ for sediments 
from Hole U1361A. From 11.7 to $11.0 \mathrm{Ma}, \mathrm{CaCO}_{3}$ increased to a maximum of $24 \%$, averaging $16.3 \%$ (Table T1).

\section{Methane concentration}

Methane concentration in Hole U1361A is elevated during the middle to late Miocene with an average concentration of $11,632 \mathrm{ppmv}$, which is 3.2 times greater than the whole core average (Fig. F3, Table T2). The highest methane concentrations are 14,739 ppmv in Core 35X (325.7 mbsf), 13,826 ppmv in Core 36X (335.3 mbsf), and 15,362 ppmv in Core $38 \mathrm{X}$ (353.5 mbsf; Core 38X is not included in this study). Concentrations reach negligible amounts by $162.7 \mathrm{mbsf}$ and remain low to the core top (see the "Site U1361" chapter [Expedition 318 Scientists, 2011b]).

\section{Hole U1361A foraminiferal data}

Foraminiferal abundances range from absent to common, and $76 \%$ of the 90 samples examined contain foraminifers. Planktonic and benthic foraminifers exhibit good to excellent preservation (Fig. F4), with the majority of benthic foraminifers having a glassy appearance. Benthic foraminifers were identified down to the species level to evaluate paleoenvironmental changes in the middle to late Miocene Southern Ocean (Table T3). Dominant species include Nuttallides umbonifera, Pullenia bulloides, O. umbonatus, Melonis pompilioides, G. soldani, E. exigua, C. wuellerstorfi, and C. bradyi. Specimens from the genus Oolina sp., Fissurina sp., Lagena spp., and Sphaeroidina sp. were also observed.

E. exigua is the most dominant benthic species throughout the majority of the study interval (Table T3); it inhabits cold and well-oxygenated waters with abundance positively correlated with seasonal phytodetritus (Smart, 2008). Cibicidoides spp. mainly occurs in the upper portion of the core from 325.35 to 313.23 mbsf and prefers cold waters with low organic matter flux (Poli et al., 2012).

\section{Stable isotopes}

Planktonic (G. bulloides) and benthic (O. umbonatus, G. soldani, E. exigua, C. wuellerstorfi, and C. bradyi) foraminifers were first run at Lamont-Doherty Earth Observatory for stable isotopes. The $\delta^{18} \mathrm{O}$ values range from $-0.3 \%$ to $2.4 \%$ for planktonic foraminifers and $1.3 \%$ to $3.3 \%$ for benthic foraminifers (Table T4; Fig. F5), and $\delta^{13} \mathrm{C}$ values range from $-15.5 \% 0$ to $0.4 \%$ o for planktonic foraminifers and -9.3 to 1.0\% for benthic foraminifers (Table T5; Fig. F5). A second set of samples were sent to Rutgers University for analysis and yielded similar results, with $\delta^{18} \mathrm{O}$ val- ues from benthic foraminifers ranging from $0.8 \%$ to $3.4 \%$ (Table T4; Fig. F5) and $\delta^{13} \mathrm{C}$ values ranging from $-12.1 \%$ o to $1.1 \%$ (Table T5; Fig. F5).

The extremely negative $\delta^{13} \mathrm{C}$ values suggest that foraminiferal calcite was diagenetically altered by the incorporation of ${ }^{13} \mathrm{C}$-depleted inorganic carbonate, likely caused by methane seeps at the core site (Martin et al., 2004; Torres et al., 2003; Rathburn et al., 2000). Foraminiferal $\delta^{13} \mathrm{C}$ values decrease to $-16 \%$ at Hole U1361A, whereas Southern Ocean values typically reach $0.4 \%$ (Wright and Miller, 1993).

Benthic foraminiferal $\delta^{18} \mathrm{O}$ values vary more than $2 \%$, which suggests unrealistically extreme changes in ice volume and temperature over short timescales $(<100 \mathrm{ky})$. The dissociation of methane hydrates has been observed to cause alterations in $\delta^{18} \mathrm{O}$ of pore waters (Torres et al., 2003) and likely caused the alteration of foraminiferal $\delta^{18} \mathrm{O}$. Interestingly, these diagenetically altered foraminifers, most of which had a glassy texture, showed little to no indication of overgrowth during visual inspection with a binocular light microscope.

A list of sample requests is found in Table T6.

\section{Acknowledgments}

Samples and data used for this research were provided by the Integrated Ocean Drilling Program (IODP). Funding for this project was from National Science Foundation (NSF) award 1130533. We would like to thank reviewer Andrew Fraass for his comments and criticisms that vastly improved this manuscript. We would also like to thank Natallia Piatrunia and Daniel Hauptvogel for their suggestions.

\section{References}

DeCesare, M., 2014. Evidence for bipolar glaciation during the middle to late Miocene interval (12-11 Ma) [M.S. thesis]. CUNY Queens College, New York.

Expedition 318 Scientists, 2011a. Methods. In Escutia, C., Brinkhuis, H., Klaus, A., and the Expedition 318 Scientists, Proceedings of the Integrated Ocean Drilling Program, 318: Tokyo (Integrated Ocean Drilling Program Management International, Inc.). http://dx.doi.org/10.2204/ iodp.proc.318.102.2011

Expedition 318 Scientists, 2011b. Site U1361. In Escutia, C., Brinkhuis, H., Klaus, A., and the Expedition 318 Scientists, Proceedings of the Integrated Ocean Drilling Program, 318: Tokyo (Integrated Ocean Drilling Program Management International, Inc.). http://dx.doi.org/ 10.2204/iodp.proc.318.109.2011

Marchant, D.R., Denton, G.H., Swisher, C.C., III, and Potter, N., Jr., 1996. Late Cenozoic Antarctic paleoclimate reconstructed from volcanic ashes in the Dry Valleys region of southern Victoria Land. Geological Society of 
America Bulletin, 108(2):181-194. http://gsabulletin.gsapubs.org/content/108/2/181.full.pdf

Martin, J.B., Day, S.A., Rathburn, A.E., Perez, M.E., Mahn, C., and Gieskes, J., 2004. Relationships between the stable isotopic signatures of living and fossil foraminifera in Monterey Bay, California. Geochemistry, Geophysics, Geosystems, 5(4):Q04004. http://dx.doi.org/10.1029/ 2003GC000629

Miller, M.F., and Mabin, M.C.G., 1998. Antarctic Neogene landscapes-in the refrigerator or in the deep freeze? GSA Today, 8(4):1-8. http://www.geosociety.org/gsatoday/archive/8/4/pdf/i1052-5173-8-4-1.pdf

Poli, M.S., Meyers, P.A., Thunell, R.C., and Capodivacca, M., 2012. Glacial-interglacial variations in sediment organic carbon accumulation and benthic foraminiferal assemblages on the Bermuda Rise (ODP Site 1063) during MIS 13 to 10. Paleoceanography, 27(3). http:// dx.doi.org/10.1029/2012PA002314

Poore, H.R., Samworth, R., White, N.J., Jones, S.M., and McCave, I.N., 2006. Neogene overflow of northern component water at the Greenland-Scotland Ridge. Geochemistry, Geophysics, Geosystems, 7(6):Q06010. http://dx.doi.org/10.1029/2005GC001085

Rathburn, A.E. Levin, L.A., Held, Z., and Lohmann, K.C., 2000. Benthic foraminifera associated with cold methane seeps on the northern California margin: ecology and stable isotopic composition. Marine Micropaleontology, 38(3-4):247-266. http://dx.doi.org/10.1016/ S0377-8398(00)00005-0

Smart, C.W., 2008. Abyssal NE Atlantic benthic foraminifera during the last $15 \mathrm{kyr}$ : relation to variations in seasonality of productivity. Marine Micropaleontology, 69(2):193-211. http://dx.doi.org/10.1016/j.marmicro.2008.07.007

Spieß, V., 1990. Cenozoic magnetostratigraphy of Leg 113 drill sites, Maud Rise, Weddell Sea, Antarctica. In Barker, P.F., Kennett, J.P., et al., Proceedings of the Ocean Drilling Program, Scientific Results, 113: College Station, TX (Ocean Drilling Program), 261-315. http://dx.doi.org/ 10.2973/odp.proc.sr.113.182.1990

Sugden, D.E., 1996. The East Antarctic Ice Sheet: unstable ice or unstable ideas? Transactions of the Institute of British Geographers, 21(3):443-454. http://dx.doi.org/ $10.2307 / 622590$

Tauxe, L., Stickley, C.E., Sugisaki, S., Bijl, P.K., Bohaty, S.M., Brinkhuis, H., Escutia, C., Flores, J.A., Houben, A.J.P.,
Iwai, M., Jiménez-Espejo, F., McKay, R., Passchier, S., Pross, J., Riesselman, C.R., Röhl, U., Sangiorgi, F., Welsh, K., Klaus, A., Fehr, A., Bendle, J.A.P., Dunbar, R., Gonzàlez, J., Hayden, T., Katsuki, K., Olney, M.P., Pekar, S.F., Shrivastava, P.K., van de Flierdt, T., Williams, T., and Yamane, M., 2012. Chronostratigraphic framework for the IODP Expedition 318 cores from the Wilkes Land Margin: constraints for paleoceanographic reconstruction. Paleoceanography, 27(2):PA2214. http:// dx.doi.org/10.1029/2012PA002308

Torres, M.E., Mix, A.C., Kinports, K., Haley, B., Klinkhammer, G.P., McManus, J., and de Angelis, M.A., 2003. Is methane venting at the seafloor recorded by $\delta^{13} \mathrm{C}$ of benthic foraminifera shells? Paleoceanography, 18(3):1062-1075. http://dx.doi.org/10.1029/ 2002PA000824

Whitehead, J.M., Quilty, P.G., Mckelvey, B.C., and O'Brien, P.E., 2006. A review of the Cenozoic stratigraphy and glacial history of the Lambert Graben-Prydz Bay region, East Antarctica. Antarctic Science, 18(1):83-99. http://dx.doi.org/10.1017/S0954102006000083

Wilson, G.S., Barron, J.A., Ashworth, A.C., Askin, R.A., Carter, J.A., Curren, M.G., Dalhuisen, D.H., Friedmann, E.I., Fyodorov-Davidov, D.G., Gilichinsky, D.A., Harper, M.A., Harwood, D.M., Hiemstra, J.F., Janecek, T.R., Licht, K.J., Ostroumov, V.E., Powell, R.D., Rivkina, E.M., Rose, S.A., Stroeven, A.P., Stroeven, P., van der Meer, J.J.M., and Wizevich, M.C., 2002. The Mount Feather Diamicton of the Sirius Group: an accumulation of indicators of Neogene Antarctic glacial and climatic history. Palaeogeography, Palaeoclimatology, Palaeoecology, 182(12):117-131. http://dx.doi.org/10.1016/S00310182(01)00455-2

Wright, J.D., and Miller, K.G., 1993. Southern Ocean influences on late Eocene to Miocene deepwater circulation. In Kennett, J.P., and Warnke, D.A. (Eds.), The Antarctic Paleoenvironment: A Perspective on Global Change. Antarctic Research Series, 60:1-25. http://onlinelibrary.wiley.com/doi/10.1002/9781118668061.ch1/ summary

Initial receipt: 27 October 2014

Acceptance: 4 December 2015

Publication: 11 March 2016

MS 318-202 
Figure F1. Location map of Site U1361 280 km off the coast of George V Land $\left(64.2457^{\circ} \mathrm{S}, 143.5320^{\circ} \mathrm{E}\right)$ and ODP Site 689 on the Maud Rise in the Weddell Sea $\left(64.5170^{\circ} \mathrm{S}, 3.0999^{\circ} \mathrm{E}\right)$.

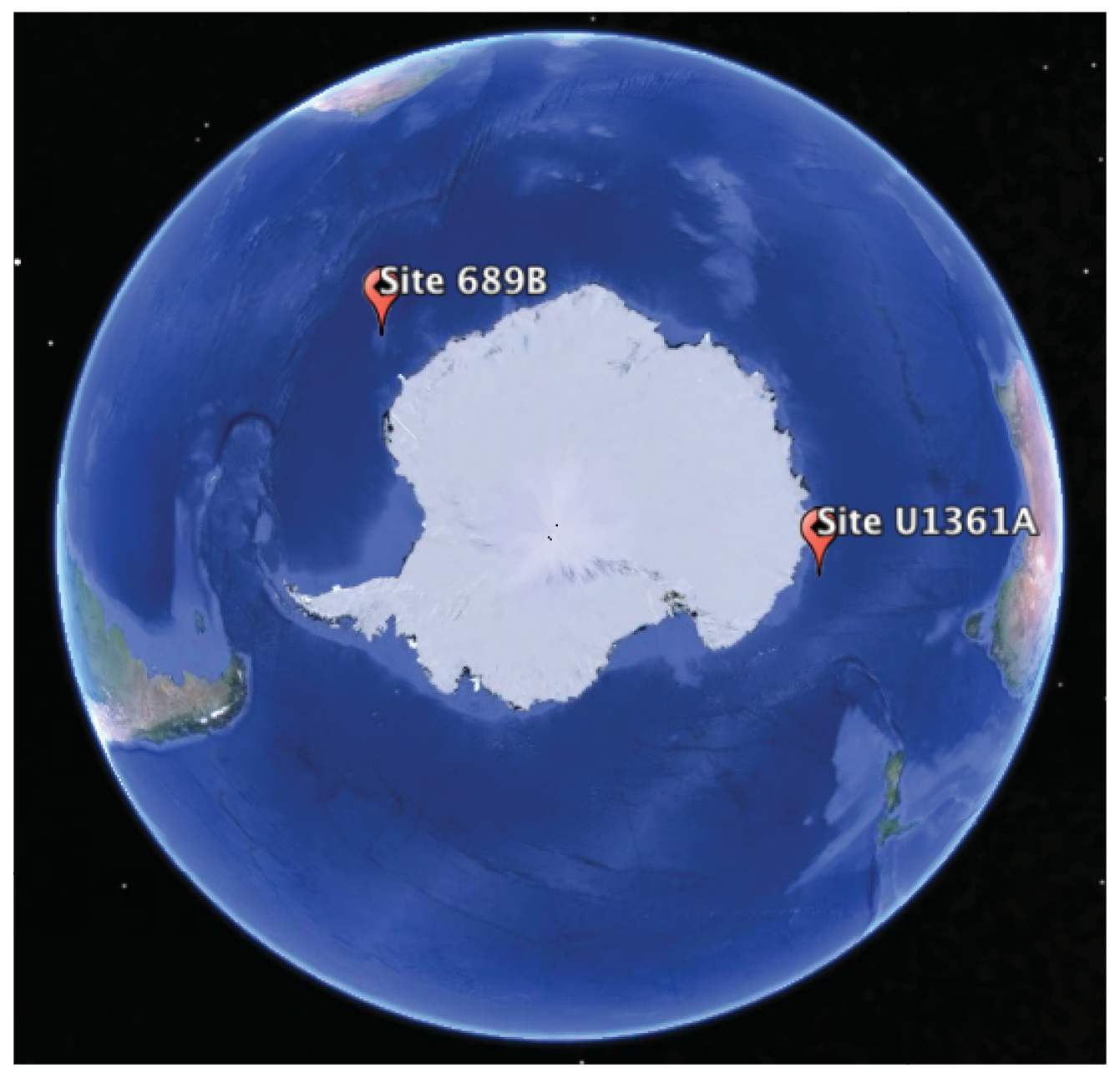


Figure F2. Age model for Hole U1361A from Tauxe et al. (2012) (Copyright 2012 American Geophysical Union), with expanded age model of the study interval using the geomagnetic tie point, Chron C5n.2n (o), at 11.04 Ma and biostratigraphic tie point and first occurrence of Denticulopsis dimorpha s.l. at 12.4 Ma.

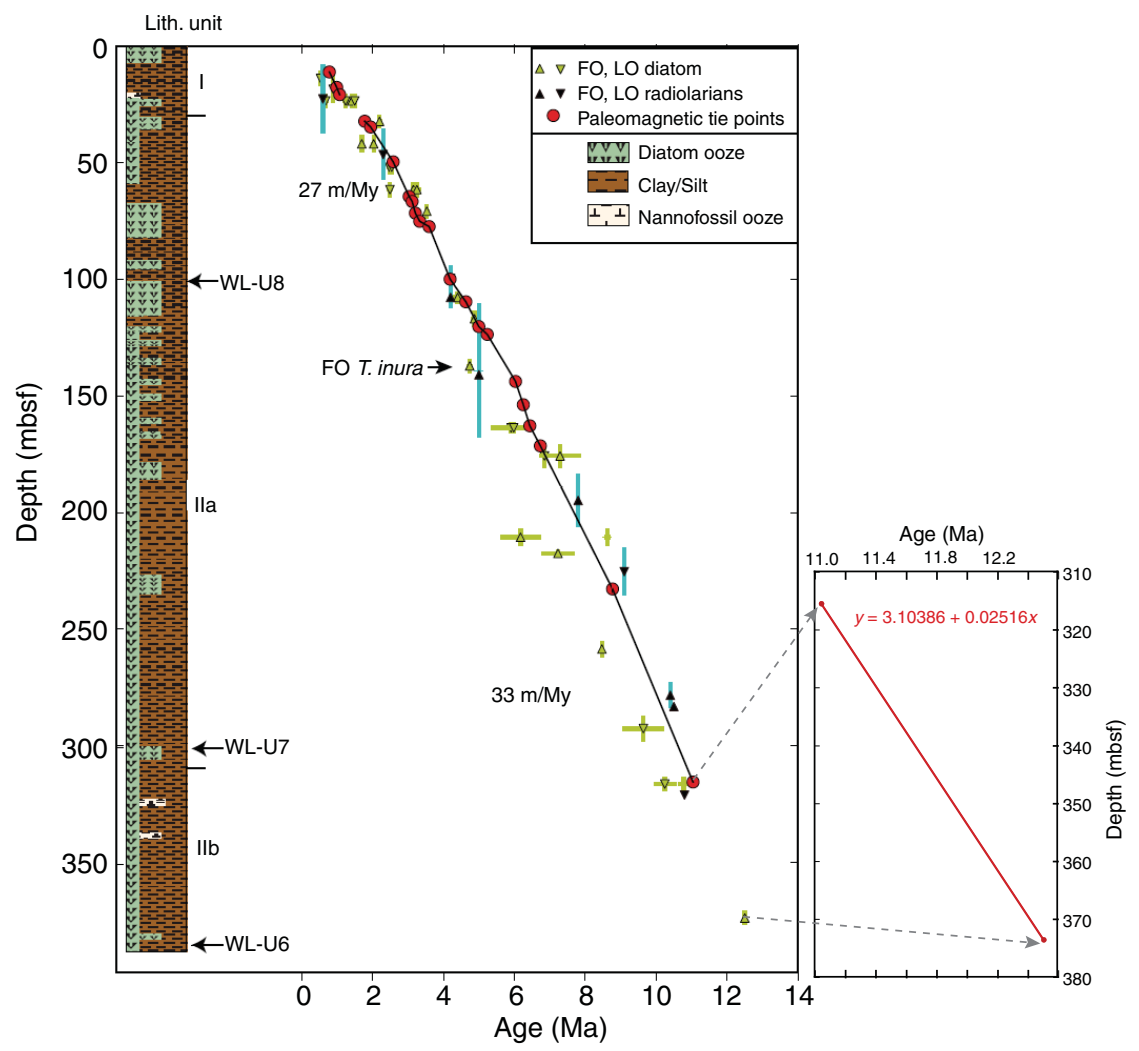


Figure F3. Methane concentrations in ppmv $\left(\times 10^{3}\right)$ and $\mathrm{CaCO}_{3}$, Hole U1361A. Gray box = study interval. Data from IODP LIMS database.

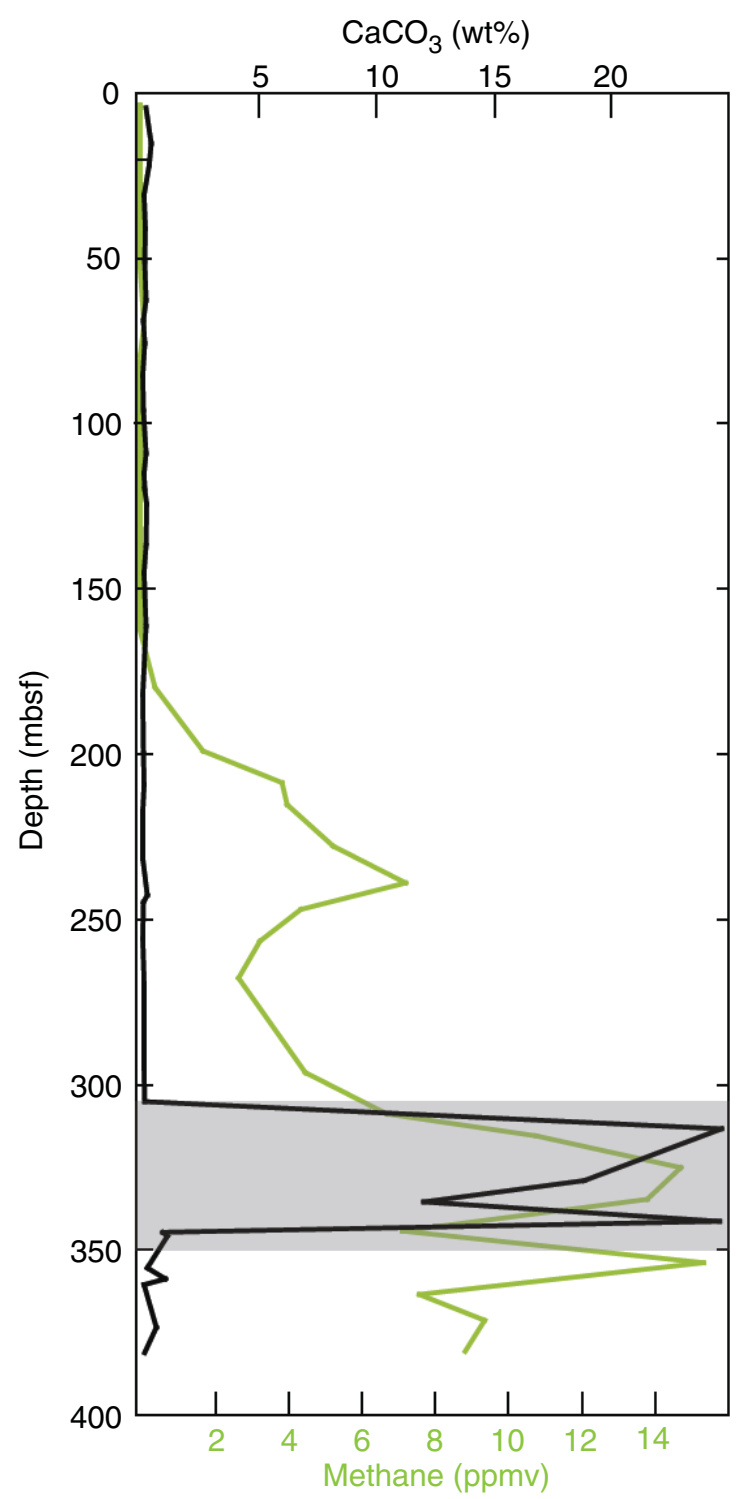


Figure F4. Light microscope images. A. G. bulloides. B. E. exigua. C. O. umbonatus. D. Melonis sp. Scale bar $=200$ $\mu \mathrm{m}$.

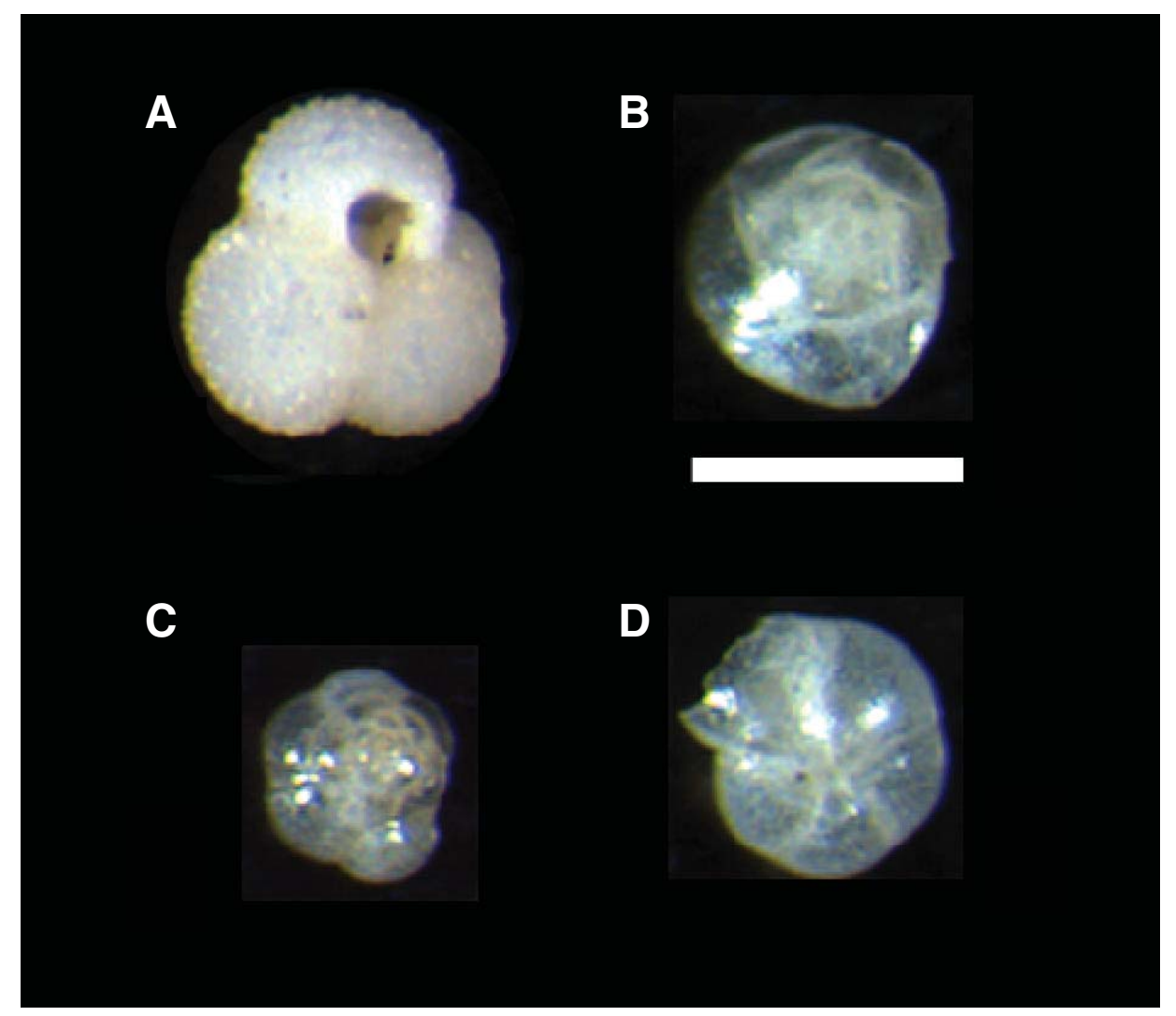


Figure F5. Stable isotope time series (raw data), Hole U1361A. Oxygen isotopes for benthic (red) and planktonic (blue) foraminifers are on the left, and carbon isotopes are on the right.

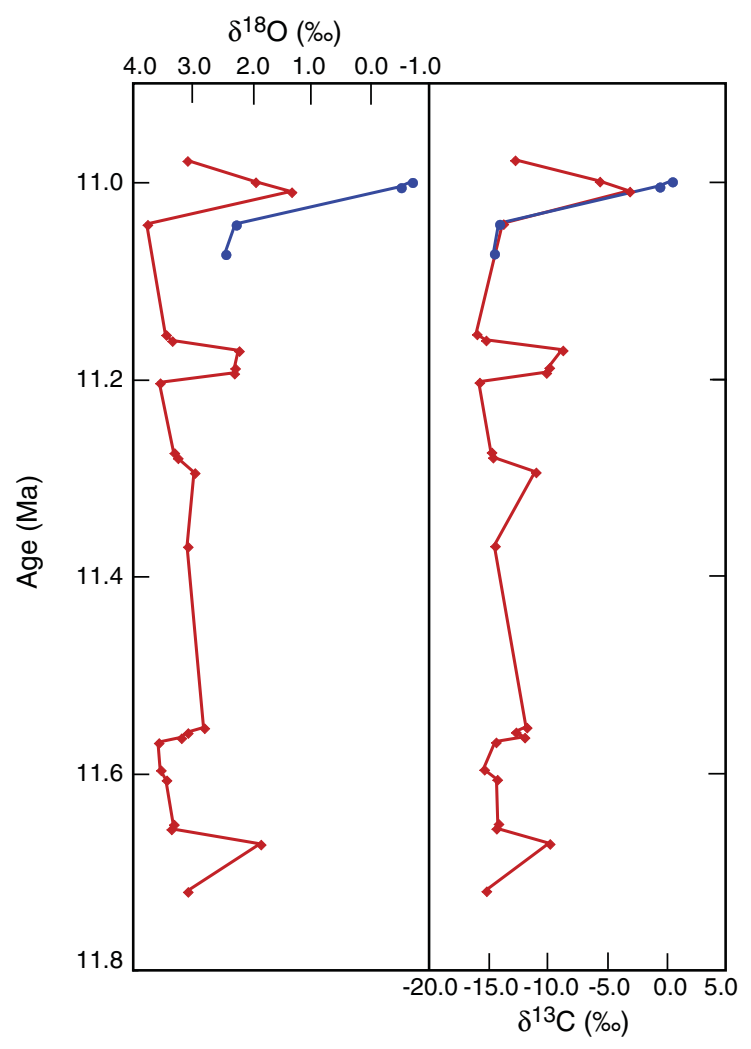


Table T1. $\mathrm{CaCO}_{3}$, Hole U1361A.

\begin{tabular}{|c|c|c|}
\hline $\begin{array}{l}\text { Age } \\
\text { (Ma) }\end{array}$ & $\begin{array}{l}\text { Top depth } \\
\text { (mbsf) }\end{array}$ & $\begin{array}{l}\mathrm{CaCO}_{3} \\
\text { (wt\%) }\end{array}$ \\
\hline & 4.9 & 0.3 \\
\hline & 15.8 & 0.5 \\
\hline & 22.2 & 0.4 \\
\hline & 31.5 & 0.2 \\
\hline & 41.7 & 0.2 \\
\hline & 51.6 & 0.2 \\
\hline & 63.0 & 0.3 \\
\hline & 69.4 & 0.2 \\
\hline & 76.3 & 0.2 \\
\hline & 86.0 & 0.1 \\
\hline & 96.4 & 0.2 \\
\hline & 109.7 & 0.3 \\
\hline & 115.6 & 0.2 \\
\hline & 120.3 & 0.2 \\
\hline & 125.0 & 0.3 \\
\hline & 137.4 & 0.3 \\
\hline & 145.9 & 0.2 \\
\hline & 161.9 & 0.3 \\
\hline & 182.7 & 0.1 \\
\hline & 200.3 & 0.2 \\
\hline & 209.9 & 0.2 \\
\hline & 218.3 & 0.1 \\
\hline & 232.2 & 0.1 \\
\hline & 243.3 & 0.3 \\
\hline & 245.4 & 0.2 \\
\hline & 256.5 & 0.1 \\
\hline & 270.0 & 0.2 \\
\hline & 295.8 & 0.2 \\
\hline & 305.7 & 0.2 \\
\hline 11.00 & 314.0 & 24.8 \\
\hline 11.40 & 329.7 & 18.9 \\
\hline 11.56 & 336.2 & 12.1 \\
\hline 11.71 & 342.0 & 24.7 \\
\hline 11.79 & 345.4 & 1.0 \\
\hline 11.82 & 346.4 & 1.2 \\
\hline 12.06 & 356.1 & 0.3 \\
\hline \multirow[t]{4}{*}{12.14} & 359.4 & 1.1 \\
\hline & 361.3 & 0.2 \\
\hline & 374.1 & 0.7 \\
\hline & 381.8 & 0.2 \\
\hline
\end{tabular}

Age control is for the middle to late Miocene. $\mathrm{CaCO}_{3}$ and depth data are from the IODP LIMS database. 
Table T2. Methane $\left(\mathrm{CH}_{4}\right)$ concentrations, Hole U1361A.

\begin{tabular}{|c|c|c|}
\hline $\begin{array}{l}\text { Age } \\
\text { (Ma) }\end{array}$ & $\begin{array}{l}\text { Depth } \\
\text { (mbsf) }\end{array}$ & $\begin{array}{c}\text { Methane } \\
\text { (ppmv) }\end{array}$ \\
\hline & 4.5 & 3 \\
\hline & 13.5 & 3 \\
\hline & 23.0 & 3 \\
\hline & 31.0 & 3 \\
\hline & 42.0 & 3 \\
\hline & 51.5 & 0 \\
\hline & 70.5 & 126 \\
\hline & 80.0 & 8 \\
\hline & 89.5 & 4 \\
\hline & 99.0 & 3 \\
\hline & 107.8 & 4 \\
\hline & 118.0 & 4 \\
\hline & 127.5 & 3 \\
\hline & 137.0 & 3 \\
\hline & 146.5 & 3 \\
\hline & 156.0 & 3 \\
\hline & 162.7 & 3 \\
\hline & 180.4 & 413 \\
\hline & 199.6 & 1,715 \\
\hline & 209.2 & 3,880 \\
\hline & 215.8 & 4,016 \\
\hline & 228.4 & 5,273 \\
\hline & 239.5 & 7,248 \\
\hline & 247.6 & 4,387 \\
\hline & 257.2 & 3,278 \\
\hline & 268.3 & 2,695 \\
\hline & 297.0 & 4,512 \\
\hline & 309.5 & 6,739 \\
\hline & 316.1 & 10,807 \\
\hline 11.2 & 325.7 & 14,739 \\
\hline 11.5 & 335.3 & 13,827 \\
\hline 11.8 & 344.9 & 7,153 \\
\hline \multirow[t]{4}{*}{12.1} & 354.5 & 15,363 \\
\hline & 364.1 & 7,612 \\
\hline & 371.9 & 9,403 \\
\hline & 381.4 & \\
\hline
\end{tabular}

Age control is for the middle to late Miocene. $\mathrm{CH}_{4}$ and depth data are from the IODP LIMS database. 


\begin{tabular}{|c|c|c|c|c|c|c|c|c|c|c|c|}
\hline $\begin{array}{l}\text { Depth } \\
\text { (mbsf) }\end{array}$ & $\begin{array}{l}\text { Age } \\
(\mathrm{Ma})\end{array}$ & $\begin{array}{l}\text { DS1 } \\
(\%)\end{array}$ & DS1 & $\begin{array}{l}\text { DS2 } \\
(\%)\end{array}$ & DS2 & $\begin{array}{l}\text { DS3 } \\
(\%)\end{array}$ & DS3 & $\begin{array}{l}\text { Specimens } \\
(N)\end{array}$ & $\begin{array}{l}\text { Spp. } \\
(N)\end{array}$ & $\begin{array}{l}\text { Weight } \\
(\mathrm{g})\end{array}$ & $\begin{array}{l}\text { Specimens/ } \\
\text { gram }\end{array}$ \\
\hline 313.23 & 11.00 & 50 & Epistominella exigua & 33 & Cibicidoides spp. & 17 & Melonis pompilioides & 6 & 3 & 15.97 & 0.38 \\
\hline 313.43 & 11.00 & 48 & Epistominella exigua & 28 & Sphaeroidina sp. & & & 60 & 9 & 16.74 & 3.58 \\
\hline 313.63 & 11.01 & 43 & Epistominella exigua & 29 & Cibicidoides spp. & 14 & Oridorsalis umbonatus & 7 & 4 & 17.25 & 0.41 \\
\hline 313.83 & 11.01 & 12 & Lagena spp. & 9 & Cibicidoides spp. & & & 114 & 13 & 19 & 6.00 \\
\hline 314.05 & 11.02 & 7 & Lagena spp. & 6 & Cibicidoides spp., Epistominella exigua & & & 165 & 16 & 18.53 & 8.90 \\
\hline 319.89 & 11.16 & 15 & Nuttallides umbonifera & 12 & Oridorsalis umbonatus & 11 & Lagena spp. & 105 & 13 & 15.52 & 6.77 \\
\hline 320.65 & 11.18 & 15 & Cibicidoides spp. & 13 & $\begin{array}{l}\text { Nuttallides umbonifera, Pullenia } \\
\text { bulloides, Fissurina sp. }\end{array}$ & & & 86 & 13 & 15.4 & 5.58 \\
\hline 321.93 & 11.22 & 24 & Epistominella exigua & 19 & Cibicidoides spp. & 14 & $\begin{array}{l}\text { Sphaeroidina sp., Melonis } \\
\text { pompilioides }\end{array}$ & 21 & 8 & 15.08 & 1.39 \\
\hline 322.85 & 11.24 & 100 & Epistominella exigua & & & & & 1 & 1 & 14.8 & 0.07 \\
\hline 323.62 & 11.26 & & & & & & & 0 & 0 & 15.32 & 0.00 \\
\hline 324.55 & 11.28 & 18 & Melonis pompilioides, Fissurina sp. & 14 & Pullenia bulloides, Epistominella exigua & & & 21 & 10 & 14.41 & 1.46 \\
\hline 325.35 & 11.30 & 39 & Cibicidoides spp. & 12 & $\begin{array}{l}\text { Pullenia bulloides, Oridorsalis } \\
\text { umbonatus }\end{array}$ & & & 98 & 16 & 16.66 & 5.88 \\
\hline 325.63 & 11.31 & & & & & & & 0 & 0 & 14.83 & 0.00 \\
\hline 327.04 & 11.34 & & & & & & & 0 & 0 & 15.55 & 0.00 \\
\hline 327.88 & 11.36 & 20 & Pullenia bulloides & 19 & Oolina spp. & 13 & $\begin{array}{l}\text { Lagena spp., Fissurina } \\
\text { sp., Oridorsalis } \\
\text { umbonatus }\end{array}$ & 16 & 8 & 17.58 & 0.91 \\
\hline 328.89 & 11.39 & & & & & & & 0 & 0 & 17.71 & 0.00 \\
\hline 329.58 & 11.41 & & & & & & & 0 & 0 & 18.72 & 0.00 \\
\hline 336.05 & 11.57 & 29 & Oridorsalis umbonatus & 15 & $\begin{array}{l}\text { Nuttallides umbonifera, Sphaeroidina } \\
\text { sp. }\end{array}$ & 13 & Cibicidoides spp. & 192 & 17 & 15.67 & 12.25 \\
\hline 336.9 & 11.59 & & & & & & & 0 & 0 & 16.86 & 0.00 \\
\hline 337.75 & 11.61 & 29 & Epistominella exigua & 14 & $\begin{array}{l}\text { Oridorsalis umbonatus, Gyroidinoides } \\
\text { soldani, Fissurina sp. }\end{array}$ & & & 21 & 8 & 18.03 & 1.16 \\
\hline 338.67 & 11.64 & 29 & Epistominella exigua, Melonis pompilioides & 14 & Fissurina sp. & & & 7 & 4 & 16.56 & 0.42 \\
\hline 339.56 & 11.66 & 52 & Epistominella exigua & 24 & Melonis pompilioides & 14 & Pullenia bulloides & 21 & 4 & 19.86 & 1.06 \\
\hline 340.55 & 11.68 & 55 & Epistominella exigua & 13 & Oridorsalis umbonatus & & & 91 & 13 & 14.23 & 6.39 \\
\hline 341.35 & 11.70 & 25 & $\begin{array}{l}\text { Oridorsalis umbonatus, Nuttallides umbonifera, } \\
\text { Melonis pompilioides, Oolina sp. }\end{array}$ & & & & & 4 & 4 & 13.55 & 0.30 \\
\hline 342.25 & 11.73 & 52 & Epistominella exigua & 18 & Oridorsalis umbonatus & 10 & Fissurina sp. & 33 & 8 & 14.72 & 2.24 \\
\hline
\end{tabular}

DS1, DS2, DS3 = benthic foraminifers categorized by the highest percentage of dominant species. E. exigua is highly abundant through the study interval. Abundance of Cibicidoides spp. increases toward upper half of the study interval. 
Table T4. Oxygen isotope $\left(\delta^{18} \mathrm{O}\right.$, raw data) separated by benthic and planktonic foraminifers, Hole U1361A.

\begin{tabular}{lrl}
\hline \multicolumn{1}{c}{ Species } & $\begin{array}{l}18 \mathrm{O} \\
\text { (\%o) }\end{array}$ & $\begin{array}{l}\text { Depth } \\
\text { (mbsf) }\end{array}$ \\
\hline $\begin{array}{lll}\text { Benthic } \\
\text { Oridorsalis umbonatus }\end{array}$ & 3.08 & 312.95 \\
Cibicidoides bradyi & 1.93 & 313.85 \\
Gyroidinoides soldani & 1.22 & 314.23 \\
Cibicidoides wuellerstorfi & 1.42 & 314.23 \\
Cibicidoides bradyi & 3.75 & 315.55 \\
Cibicidoides wuellerstorfi & 3.43 & 320.01 \\
Cibicidoides spp. & 3.33 & 320.25 \\
Cibicidoides wuellerstorfi & 2.24 & 320.65 \\
Cibicidoides wuellerstorfi & 2.14 & 320.65 \\
Cibicidoides wuellerstorfi & 2.25 & 320.65 \\
Cibicidoides bradyi & 2.40 & 321.35 \\
Cibicidoides wuellerstorfi & 2.15 & 321.35 \\
Oridorsalis umbonatus & 2.34 & 321.53 \\
Oridorsalis umbonatus & 2.45 & 321.53 \\
Epistominella exigua & 2.07 & 321.53 \\
Cibicidoides wuellerstorfi & 3.54 & 321.93 \\
Cibicidoides wuellerstorfi & 3.30 & 324.75 \\
Cibicidoides wuellerstorfi & 3.24 & 324.95 \\
Cibicidoides wuellerstorfi & 2.96 & 325.55 \\
Cibicidoides wuellerstorfi & 3.07 & 328.54 \\
Oridorsalis umbonatus & 2.79 & 335.85 \\
Oridorsalis umbonatus & 3.05 & 336.05 \\
Oridorsalis umbonatus & 3.08 & 336.05 \\
Gyroidinoides soldani & 3.34 & 336.26 \\
Oridorsalis umbonatus & 2.98 & 336.26 \\
Cibicidoides wuellerstorfi & 3.21 & 336.26 \\
Cibicidoides wuellerstorfi & 3.49 & 336.45 \\
Cibicidoides bradyi & 3.62 & 336.45 \\
Epistominella exigua & 3.54 & 337.55 \\
Cibicidoides wuellerstorfi & 3.50 & 337.55 \\
Epistominella exigua & 3.59 & 337.95 \\
Oridorsalis umbonatus & 3.26 & 337.95 \\
Epistominella exigua & 3.47 & 339.76 \\
Oridorsalis umbonatus & 3.14 & 339.76 \\
Epistominella exigua & 3.34 & 339.96 \\
Epistominella exigua & 1.84 & 340.55 \\
Cibicidoides bradyi & 3.07 & 342.46 \\
Planktonic & & \\
Globigerina bulloides & -0.72 & 313.85 \\
Globigerina bulloides & -0.24 & 314.03 \\
Globigerina bulloides & -0.81 & 314.03 \\
Globigerina bulloides & 2.26 & 315.55 \\
Globigerina bulloides & 2.44 & 316.72 \\
\hline & & \\
\hline
\end{tabular}


Table T5. Carbon isotope $\left(\delta^{13} \mathrm{C}\right.$, raw data) separated by benthic and planktonic foraminifers, Hole U1361A.

\begin{tabular}{lrl}
\multicolumn{1}{c}{ Species } & $\delta^{13}$ C & Depth \\
\hline (\%o) & (mbsf) \\
\hline Benthic & & \\
Oridorsalis umbonatus & -2.19 & 312.95 \\
Cibicidoides bradyi & -9.31 & 313.85 \\
Gyroidinoides soldani & -12.11 & 314.23 \\
Cibicidoides wuellerstorfi & -11.61 & 314.23 \\
Cibicidoides bradyi & -1.19 & 315.55 \\
Cibicidoides wuellerstorfi & 1.02 & 320.01 \\
Cibicidoides spp. & 0.26 & 320.25 \\
Cibicidoides wuellerstorfi & -5.98 & 320.65 \\
Cibicidoides wuellerstorfi & -6.59 & 320.65 \\
Cibicidoides wuellerstorfi & -6.02 & 320.65 \\
Cibicidoides bradyi & -5.12 & 321.35 \\
Cibicidoides wuellerstorfi & -5.00 & 321.35 \\
Oridorsalis umbonatus & -4.21 & 321.53 \\
Oridorsalis umbonatus & -4.23 & 321.53 \\
Epistominella exigua & -6.00 & 321.53 \\
Cibicidoides wuellerstorfi & 0.82 & 321.93 \\
Cibicidoides wuellerstorfi & -0.21 & 324.75 \\
Cibicidoides wuellerstorfi & -0.33 & 324.95 \\
Cibicidoides wuellerstorfi & -3.93 & 325.55 \\
Cibicidoides wuellerstorfi & -0.48 & 328.54 \\
Oridorsalis umbonatus & -3.17 & 335.85 \\
Oridorsalis umbonatus & -2.10 & 336.05 \\
Oridorsalis umbonatus & -2.37 & 336.05 \\
Gyroidinoides soldani & -4.76 & 336.26 \\
Oridorsalis umbonatus & -3.06 & 336.26 \\
Cibicidoides wuellerstorfi & -1.16 & 336.26 \\
Cibicidoides wuellerstorfi & -0.43 & 336.45 \\
Cibicidoides bradyi & -0.69 & 336.45 \\
Epistominella exigua & -0.30 & 337.55 \\
Cibicidoides wuellerstorfi & 1.11 & 337.55 \\
Epistominella exigua & -0.18 & 337.95 \\
Oridorsalis umbonatus & -1.19 & 337.95 \\
Epistominella exigua & -0.44 & 339.76 \\
Oridorsalis umbonatus & -1.14 & 339.76 \\
Epistominella exigua & -0.60 & 339.96 \\
Epistominella exigua & -5.10 & 340.55 \\
Cibicidoides bradyi & 0.23 & 342.46 \\
Planktonic & & \\
Globigerina bulloides & -15.45 & 313.85 \\
Globigerina bulloides & -13.38 & 314.03 \\
Globigerina bulloides & -15.35 & 314.03 \\
Globigerina bulloides & -0.86 & 315.55 \\
Globigerina bulloides & -0.43 & 316.72 \\
\hline & & \\
\hline
\end{tabular}


Table T6. Sample request database.

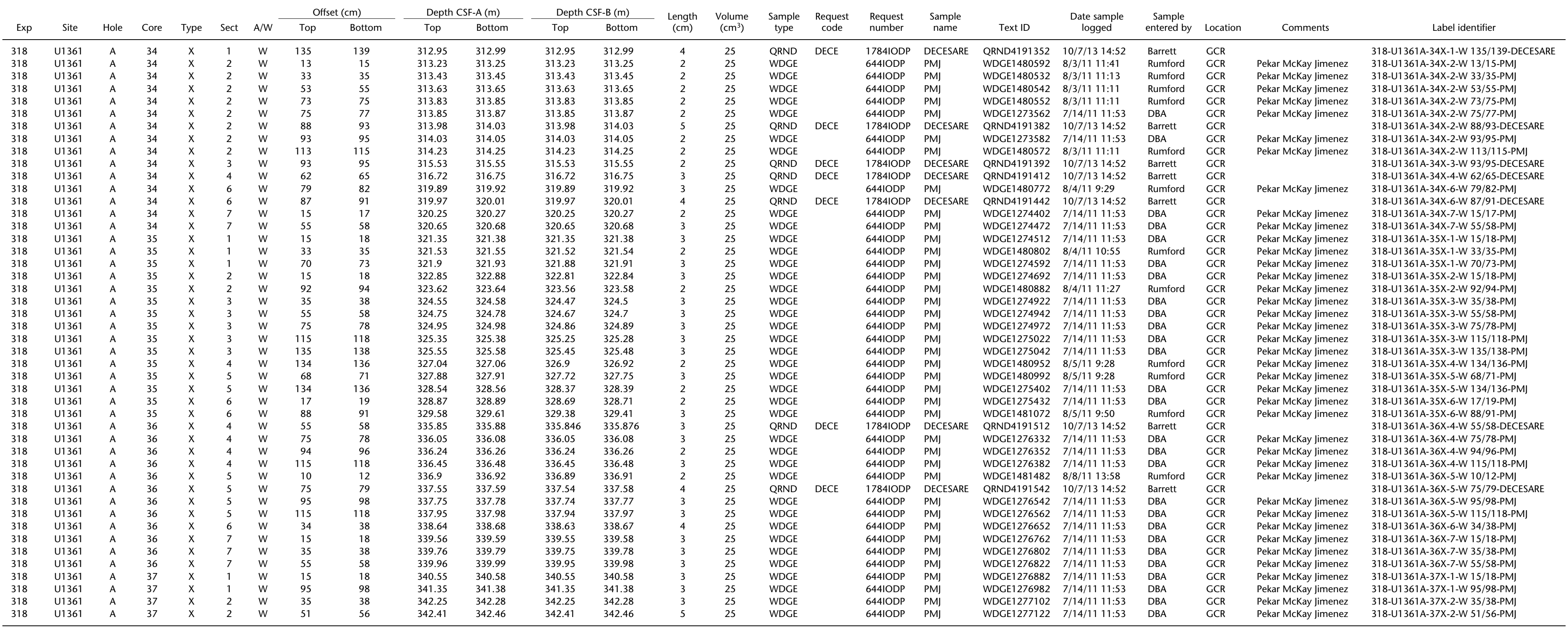

